\title{
KEKERASAN SUAMI TERHADAP ISTRI DALAM WACANA HAK ASASI MANUSIA
}

\author{
Erfaniah Zuhriah \\ Dosen Fakultas Syari'ah UIN Malang
}

\begin{abstract}
Abstrak
All sort of physical and phsycological violences generating from gender bias practices toward role and position of women in the family are legally not allowed based on international declaration on Human rights as those violences neglect basic rights of individuals. Domestic violence, as one example of gender bias practice, is legally prohibited for its subordination, marginalization and streotype toward men or women in a domestic relationship context. It maybe safely argued that any forms of differences which are constructed based on gender bias perspective may result in inequality and violences. Therefore, gender role division refers to husband-wife right and obligation under religious normative doctrines and socio-cultural understanding are not tolerated and can be categorized as breaking the legal regulation of human rights.
\end{abstract}

\section{A. Pendahuluan}

Tindakan kekerasan apapun bentuknya akan mengakibatkan hak-hak dasar sesorang teraniaya, termasuk bentuk kekerasan dalam rumah tangga baik dalam bentuk tindakan kekerasan fisik seperti pemukulan, mengigit, menampar dan pencederaan fisik lainnya, penganiayaan non fisik yang bertujuan merendahkan citra dan kepercayaan diri seorang, baik melalui kata-kata atau perbuatan yang tidak disukai oleh korban, maupun tindakan kekerasan psikologis yang merupakan tindakan terselubung yang mengakibatkan hak dasar manusia diabaikan, sebab seorang manusia dilahirkan merdeka dan memiliki hak-hak yang sama sehinga mereka juga berhak untuk memperoleh perlakuan yang baik.

Dalam aspek ekonomi perempuan juga mengalami bentuk relasi yang tidak seimbang dengan laki-laki. Istri dalam rumah tangga selain tidak diberikan hak untuk keluar rumah dengan leluasa atau harus dengan seizin suami, perempuan juga tidak memiliki hak untuk membelanjakan maupun melakukan transaksi harta suami bahkan hartanya sendiri. Hal tersebut dapat merugikan perempuan karena ia dipandang sebagai pihak kedua dan dipinggir dibanding dengan peran dan posisi 
laki-laki yang memiliki kekuasaan yang dominan baik dari segi aspek sosial maupun ekonomi. Tentu saja hal ini dapat mengakibatkan semakin lemahnya posisi perempuan karena dalam aspek ekonomi pun perannya berada dalam posisi marginal.

Jika pelabelan terhadap citra perempuan dibangun dengan tidak seimbang dengan laki-laki, maka pola relasi yang tercipta dalam rumah tangga akan mengarah pada pola relasi antara "atasan dan bawahan" dimana istri harus mematuhi kemauan dari suami tanpa ada posisi tawar terutama dalam masalah seksual. Dalam hal ini perempuan bisa digambarkan sebagai objek seks dari suami. Ironisnya, dalam kitab tersebut tidak dijelaskan bagaimana seharusnya laki-laki juga mempunyai kewajiban yang sama dan posisi tawar yang sama dengan perempuan. Seharusnya suami juga mempunyai kewajiban untuk menyenangkan hati istri dengan berdandan dan dilarang untuk menolak jika istri menginginkan berhubungan seksual. Oleh karena itu, pengklasifikasian antara perempuan dan laki-laki menurut tinjaun kitab Uqud Al-Lujjayn bisa dikatakan sangat bias gender dan tidak mengikuti apa yang sudah tertera dan disepakati oleh Undang-Undang HAM.

\section{B. Kedudukan dan Pola Relasi Suami Istri dalam Analisis HAM}

Sekarang ini fakta kekerasan yang terjadi didalam rumah tangga, tidak lagi menjadi persoalan yang dianggap biasa, dan merupakan persoalan internal antara suami dan istri. Kekerasan dalam rumah tangga saat ini mencuat kepermukaan karena tidak lagi menjadi wacana belaka, akan tetapi merupakan persoalan konkrit yang banyak dialami oleh sebagian besar perempuan didunia.

Dalam perspektif Hak Asasi Manusia, tindak kekerasan dalam rumah tangga yang dilakukan oleh suami terhadap istri, merupakan tindakan yang melanggar prinsip-prinsip dasar dalam Deklarasi sedunia Hak Asasi Manusia. Prinsip tersebut diantaranya adalah menyangkut hak dasar yang dimiliki oleh setiap manusia, khususnya terhadap hak-hak perempuan, melalaui deklarasi penghapusan kekerasan terhadap perempuan 
"Convention on the Elimination of all form of Discrimination Against Woman" (CEDAW), yaitu Deklarasi PBB mengenai penghapusan segala bentuk diskriminasi terhadap perempuan yang memuat hak dan kewajiban berdasarkan atas persamaan hak dengan pria dan menyatakan agar negara mengambil langkah-langkah seperlunya untuk melaksanakanya ${ }^{1}$

Dalam tinjauan Hak Asasi Manusia kekerasan dalam rumah tangga merupakan tindakan yang secara umum bertentangan dengan deklarasi umum HAM (DUHAM) PBB-1948 dan Undang-Undang 39 Tahun 1999 tentang HAM. Kekerasan merupakan bentuk tindakan yang tidak memperhatikan hak-hak dasar yang dimiliki manusia, hak-hak dasar tersebut diantaranya adalah hak hidup,hak persamaan, hak perlindungan dan kehormatan, hak keamanan dan kesucian kehidupan pribadi, hak perlindungan hukum, hak untuk mendapat pelayanan kesehatan fisik maupun mental yang sebaik-baiknya, hak kebebasan berekspresi serta kebebasan hati nurani dan keyakinan, hak atas pekerjaan yang layak dan kondisi kerja yang baik, hak untuk pendidikan lanjut, hak untuk tidak mengalami penganiayaan atau bentuk kekejaman lain, serta perlakuan atau penyiksaan secara tidak manusiawi yang sewenang-wenang.

Tindakan kekerasan apapun bentuknya akan mengakibatkan hak-hak dasar sesorang teraniaya, termasuk bentuk kekerasan dalam rumah tangga baik dalam bentuk tindakan kekerasan fisik seperti pemukulan, mengigit, menampar dan pencederaan fisik lainnya, penganiayaan non fisik yang bertujuan merendahkan citra dan kepercayaan diri seorang, baik melalui kata-kata atau perbuatan yang tidak disukai oleh korban, maupun tindakan kekerasan psikologis yang merupakan tindakan terselubung yang mengakibatkan hak dasar manusia diabaikan, sebab seorang manusia dilahirkan merdeka dan memiliki hak-hak yang sama sehinga mereka juga berhak untuk memperoleh perlakuan yang baik.

Dalam pasal 1 Deklarasi universal HAM disebutkan bahwa setiap manusia berhak atas penghidupan, kemerdekaan dan keselamatan sesorang. Pasal 4 menyebutkan pula bahwa tidak seorangpun boleh dianiaya atau diperlakukan secara kejam dengan tidak mengingat ataupun cara perlakuan atau hukuman yang

${ }^{1}$ Aina Rumiyati Azis, 2002. 
menghinakan. Nursyahbani Katjasungkana dari koalisi perempuan Indonesia menyatakan bahwa kekerasan dalam bentuk apapun merupakan pelanggaran terhadap hak asasi manusia, karenanya kewajiban Negara untuk memastikan bahwa tidak ada impunity atau pembiaran terhadap pelanggraan HAM yang terjadi termasuk dalam persoalan Kekerasan dalam rumah tangga (KDRT) atau kekerasan domestik. Pengertian perlindungan atas HAM ini juga harus diperluas, tidak dalam pengertian proteksi tapi juga dalam pengertian melaksanakan kewajiban untuk melakukan tindakan yang perlu dalam mencegah dan mengulangi pelanggaran yang terjadi ${ }^{2}$

Salah satu yang masuk kategori sebagai kekerasan perempuan baik dilingkungan rumah tangga maupun didepan umum, baik sektor domestik maupun publik, yang saat ini sudah mulai menjadi perhatian dalam konverensi PBB tentang penghapusan kekerasan terhadap perempuan adalah perkosaan dalam perkawinan (marital rape). Dalam kasus perkosaan yang dilakukan suami terhadap istri memang didalam KUHP di Indonesia masih belum diatur secara rinci, sehingga sampai sekarangpun marital rape masih belum tersentuh sama sekali, namun dalam prinsip-pinsip dasar yang tercantum dalam piagam PBB, jelas sekali segala macam tindak kekerasan termasuk kekerasan dalam rumah tangga tidak dapat dibenarkan.

Sedangkan menurut pasal 1 deklarasi penghapusan kekerasan terhadap perempuan sudah disebutkan bahwa kekerasan terhadap perempuan adalah setiap tindakan berdasarkan perbedaan jenis kelamin yang berakibat atau mungkin berakibat kesengsaran atau penderitaan perempaun secara fisik, seksual atau psikologis, termasuk ancaman tindakan tertentu, pemaksaan atau perampasan kemerdekaan secara sewenang-wenang, baik yang terjadi di depan umum atau dalam kehidupan pribadi, sedangkan perkosaan (menurut pasal 2 deklarasi tersebut) dikategorikan sebagai salah satu bentuk tindak kekerasan terhadap perempuan.

Berdasarkan deklarasi tersebut, dapat dimengerti bahwa salah satu tindakan yang menimbulkan kesengsaran atau penderitaan perempuan dalam bentuk

\footnotetext{
${ }^{2}$ Bali Post, Juli 2002.
} 
apapun merupakan kejahatan yang melanggar HAM. Lebih-lebih berakibat ganda yaitu selain penderitaan yang bersifat fisik akibat yang paling berat dan membutuhkan penyembuhan jangka panjang yaitu derita sosial dan psikologis. Artinya dari aspek HAM tindakan apapun yang telah menyengsarakan hak-hak perempuan merupakan kekerasan yang tidak dapat dibenarkan, termasuk perlakuan kasar suami terhadap istri dalam sebuah rumah tangga. Nursyahbani Kanjasungkana kembali menyebutkan "Perkosaan" sebagai salah satu bentuk kekerasan terhadap perempuan adalah contoh kerentanan posisi perempuan utamanya terhadap kepentingan seksual laki-laki citra seksual perempuan yang ditempatkan jauh pada kehidupan perempaun, sehingga dia terpaksa harus selalu menghadapi kekerasan, pemaksaan dan penyiksaan fisik dan psikis. ${ }^{3}$

Sering perempuan menjadi objek kekerasan utamanya oleh kepentingan seksual laki-laki menempatkan perempaun pada posisi dibawah laki-laki, padahal dalam tinjauan Teologis kedudukan perempuan setara dan saling melengkapi. Menurut Ida Bagus Gde Yudha Triguna dari UNHI dalam makalahnya mengungkapkan: dalam Siswatatwa dikenal konsep Ardaniswari, yaitu simbul Tuhan dalam manifestasi sebagai setengah Purusa dan Pradana. Makna simbolis dari konsep Ardanariswari itu, kedudukan dan peranan wanita setara dan saling melengkapi dengan laki-laki, malahan dimuliakan. " Tidak ada alasan serta argumentasi teologis yang menyatakan bahwa kedudukan wanita berada dibawah laki-laki. ${ }^{4}$

Dengan pandangan tersebut tidak ada alasan bagi laki-laki untuk melakukan kesewenang-wenangan artinya tindak kekerasan baik penganiayaan, ancaman serta penghilangan atas kemerdekaan perempaun tidak dibenarkan dan jika hal ini dibiarkan maka posisi wanita selamanya berada diantara kekuasaan laki-laki, karena itu perempaun selalu berada didalam subordinasi kaum laki-laki.

Sehingga perilindungan dan keamanan terhadap hak-hak perempuan harus terus terjamin lebih-lebih persoalan kekerasan terhadap perempuan dalam rumah tangga (KDRT) yang rentan dan tidak mudah diungkap kepermukaan. Kasus

\footnotetext{
${ }^{3}$ Abdul Wahid, Muhammad Irfan, Perlindungan terhadap korban kekerasan Seksual, 2001: 65.

${ }^{4}$ Bali Pos, 2002
} 
kekerasan terhadap segala bentuknya, menurut Yudha Triguna adalah sesuatu yang dilarang oleh ajaran agama Hindu. Kekerasan dalam rumah tangga (KDRT) terlebih hal itu dilakukan terhadap kaum perempuan, maka tindakan itu tidak hannya melanggar hukum alam, tetapi juga telah melanggar etika sosial rumah tangga. Tindakan kekerasan dapat menyebabkan kemunduran dalam kualitas reinkarnasi. ${ }^{5}$

Persoalan Kekerasan dalam rumah tangga sampai sekarang masih menjadi polemik terutama beberapa kasus didalamnya yang belum tersentuh secara spesifik oleh KUHP di Indonesia, terutama kasus marital rape (perkosaan dalam perkawinan) baik dalam bentuk dan alasan apapun. Memang diakui selama ini banyak kasus kekerasan dalam rumah tangga yang belum sepenuhnya dilayani secara baik oleh Negara-negara dibelahan dunia, meskipun banyak diantara Negara tersebut yang telah meratifikasi dan menandatangani konvensi penghapusan diskriminasi terhadap perempuan.

Dalam tinjauan historis banyak sekali pembentukan komisi yang tujuan untuk memberikan hak maupun perlindungan terhadap perempuan di Dunia misalnya saja konvensi tentang hak-hak sipil dan politik serta konvensi hak ekonomi sosial dan budaya. Namun konvensi tersebut lebih melindungi persoalanpersoalan kekerasan disektor publik terutama kekerasan terhadap laki-laki atau perempuan yang berhubungan dengan kepentingan Negara, sedangkan bentukbentuk kekerasan disektor privat yang terkait dengan hubungan antar personal tidak memperoleh perhatian sama sekali.

Setelah satu atau dua tahun sesudah tahun 1948 dibentuk CSW (Commision on the Status of Women) sebuah komisi yang bertugas untuk memperoleh rekomendasi dan laporan pada U.N, untuk meningkatkan status perempuan dibidang politik, ekonomi, sipil, sosial dan pendidikan. Pada waktu itu, Eleoners Roosevelt-istri presiden Amerika waktu itu yang ikut membuat rancangan DUHAM, menyadari bahwa ternayata persoalan perempuan tidak tercover atau tidak dilindungi didalamnya, kemudian Eleoners Roosevelt membentuk satu komisi yakni Commission on the status of Women (CSW) untuk mempersiapkan 
UU atau konvensi yang melindungi perempaun berdasarkan laporan-laporan atau kasus-kasus terhadap perempuan seperti penindasan marginalisasi dibidang politik, ekonomi, sosial budaya dan pendidikan.

Pada tahun 1957 muncul pula konvensi tentang hak warga Negara bagi perempuan yang menikah. Dalam konvensi tersebut muncul ketentuan bahwa perempuan menikah tidak harus mengikuti warganegara suaminya tetapi berhak menentukan dan memilih warganegara seperti dengan keinginannya. Pada tahun 1960 UNESCO mendesak PBB untuk mengeluarkan konvensi anti diskriminasi pendidikan, karena menurut penelitian UNESCO terbukti bahwa gender telah mengakibatkan perempuan tidak mendapat akses informasi pendidikan dan lain sebagainya. Hal tersebut pada alirannya membuat perempuan tetap terkurung didalam rumah dan tidak bisa mengembangkan potensi dirinya sebagai manusia. ${ }^{6}$

Pada tahun berikutnya, setelah melewati dua konvensi besar, maka dalam suatu konvensi besar perempuan pertama sedunia di Mexico. Mengisyaratkan kondisi perempuan masih terpuruk, masih miskin baik nutrisi, pendidikan, informasi atau dengan pengertian lain perempuan berada dikelas dua, karena persoalan gender, maka pada tahun 1978 PBB mensyahkan konvensi baru yaitu CEDAW (convention for the elimination of dis crimination against women), yaitu konvensi anti diskriminasi terhadap perempuan. CEDAW telah diratifikasi oleh 139 negara anggota PBB termasuk Indonesia, CEDAW merupakan konvensi hak asasi manusia yang menjabarkan persoalan-persoalan HAM dalam DUHAM dari perspektif perempuan. ${ }^{7}$

Dengan disahkan CEDAW maka secara konvensi ini diakui dan memiliki tempat di U.N Deklaration of Human Righ. Hak-hak perempaun yang selama ini menglami penindasan dan sangat dilupakan dan tidak terkover oleh DUHAM, maka dengan adanya CEDAW hak asasi manusia perempaun sejak tahun 1929 secara resmi diakui oleh DUHAM yang sudah diratifikasi oleh PBB, ini berarti bahwa bagi setiap Negara yang menandatangani atau meratifikasi konvensi tersebut harus memasukkan unsur CEDAW kedalam hukum nasionalnya yang

\footnotetext{
${ }^{6}$ Ita F Nadia, Hak Perempuan sebagai HAM (Deminasi HAM), 2000: 119.

${ }^{7}$ Ibid., 120 .
} 
sekaligus berarti Negara tersebut menyetujui tindakan-tindakan anti diskriminasi terhadap perempuan. CEDAW mensyaratkan kepada semua Negara yang meratifikasi untuk mengimplementasikannya kedalam peraturan hukum yaitu peraturan anti diskriminasi terhadap perempuan.

Indonesia meratifikasi konvensi ini pada tahun 1984. untuk memperkuat CEDAW, karena didalam CEDAW tidak tercakup satu draf yaitu tentang kekerasan terhadap perempuan, CSW kemudian mengajukan suatu draf yaitu deklarasi anti kekerasan terhadap perempuan yang didesakkan pada tahun 1992, deklarasi ini kemudian disahkan pada konfrensi Wina. Dengan disahkannya deklarasi ini, maka kekerasan terhadap perempuan yang sebelumnya dianggap sebagai persoalan privat, persoalan rumah tangga, kini diangkat ketingkat publik bahkan tingkat Internasional kekerasan terhadap kaum perempuan disektor privat (sektor domestik) merupakan pelanggaran hak asasi manusia.

Pada konfrensi Dunia HAM di Wina tahun 1992, semua peserta konverensi baik laki-laki maupun perempuan, bersepakat untuk menginterpretasikan hak asasi manusia berdasarkan perspektif perempun dengan bertujuan untuk mengenali tindak kekerasan terhadap perempaun disektor privat dan harus diangkat disektor publik, disamping itu kritik terhadap DUHAM dilontarkan oleh perempuan muslim dari Pakistan (Women Action Forum). WAF mencoba membahas poin demi poin DUHAM dari perspektif perempuan dan kemudian mengupayakan memasukkan unsur kekerasan terhadap perempaun dalam deklarasi tersebut. Dengan demikian, sesungguhnya sudah ada kemajuan pada DUHAM yang diresmikan oleh adanya perubahan pasal yang berperspektif perempaun. Pada tahun1994 diselengarakan konverensi hak asasi manusia di Genewa. Dalam konverensi ini semua negara mengadukan berbagai kasus pelanggaran hak asasi manusia dan mencoba kembali seluruh konvensi hak asasi manusia berperspektif perempaun. ${ }^{8}$

Meskipun hak-hak perempuan terwadahi dengan disahkannya CEDAW oleh PBB sebagai bagian DUHAM, kekerasan terhadap perempaun didunia masih banyak terjadi. Dalam laporan PBB tentang keadaan penduduk PBB berjudul

${ }^{8}$ Ibid., 121-122. 
"lives together, world apart-state of world population 2000 mencatat bahwa satu dari tiga perempaun pernah mengalami kekerasan atau pemukulan. Sebanyak dua juta gadis dipaksa memasuki dunia pelacuran setiap tahunya, sekitar 5 ribu wanita setiap tahunnya menjadi korban apa yang disebut "honor filling" atau pembunuhan atas nama membela martabat keluarga dan 4 juta perempaun atau gadis dijualbelikan baik untuk perkawinan, pelacuran, atau perbudakan. ${ }^{9}$

Fakta-fakta kekerasan terhadap perempuan baik bentuk maupun jenisnya banyak terjadi di dunia, termasuk terjadi pula di Indonesia. Fakta tersebut dapat dilihat dari sebuah sumber yang tercantum dalam table sebagai berikut:

Tabel : Berbagai Fakta Kekerasan Terhadap Perempuan di Dunia dan di Indonesia

\begin{tabular}{|c|c|c|}
\hline $\begin{array}{l}\text { Wilayah Kekerasan } \\
\text { Terhadap Perempaun }\end{array}$ & Dunia & Indonesia \\
\hline $\begin{array}{l}\text { Kekerasan fisik, } \\
\text { seksual dan } \\
\text { psikologis yang } \\
\text { terjadi didalam } \\
\text { keluarga }\end{array}$ & $\begin{array}{l}\text { a. Kekerasan dalam } \\
\text { rumah tangga dialami } \\
\text { oleh } 20-50 \% \\
\text { perempaun (UN, } \\
\text { 1997). } \\
\text { b. Female genital } \\
\text { multilation } \\
\text { diperkirakan setiap } \\
\text { tahun dua juta anak } \\
\text { perempuan menerima } \\
\text { sunat atau mutilasi } \\
\text { (UN, 1997). } \\
\text { c. dalam sebuah studi di } \\
\text { Kanada tahun } 1993 \\
\text { (N=420), ditemukan } \\
\text { 54\% pernah } \\
\text { mengalami bentuk } \\
\text { kegitaan seksual yang } \\
\text { tidak diinginkan } \\
\text { sebelum umur } 16 \\
\text { tahun, sekitar } 51 \% \\
\text { dilaporkan menjadi } \\
\text { korban perkosaan } \\
\text { atau upaya perkosaan } \\
\text { (UN, 1995). } \\
\text { d. Sebuah studi yang } \\
\text { dilakukan pada } \\
\text { Negara-negara di } \\
\text { Asia selatan } \\
\text { ditemukan bahwa } \\
\text { dalam jangkah dua }\end{array}$ & $\begin{array}{l}\text { a. Suami membentak istri, suami } \\
\text { main seromg, suami tidak } \\
\text { memberi uang belanja cenderung } \\
\text { kurang dianggap sebagai tindak } \\
\text { kekerasan oleh suami } \\
\text { sememntara istri meniali sebagai } \\
\text { tindakan kekerasan (Kollahann, } \\
\text { 1998). }\end{array}$ \\
\hline
\end{tabular}

${ }^{9}$ Aina Rumiyati Aziz, 2002. 


\begin{tabular}{|c|c|c|}
\hline & $\begin{array}{l}\text { setengah tahun } \\
\text { terdapat } 58 \% \\
\text { pembunuhan bayi } \\
\text { perempuan dengan } \\
\text { cara memberikan } \\
\text { getah dari tanaman } \\
\text { beracun pada } \\
\text { makanan bayi atau } \\
\text { dengan membuat } \\
\text { bayi tersedak akibat } \\
\text { adanya butiran beras } \\
\text { dalam susunya } \\
\text { sehingga tersangkut } \\
\text { di tenggorokan bayi } \\
\text { (UN, 1995). }\end{array}$ & \\
\hline $\begin{array}{l}\text { Kekerasan secara } \\
\text { fisik, seksual dan } \\
\text { psikologis yang } \\
\text { terjadi dalam } \\
\text { masyarakat }\end{array}$ & $\begin{array}{l}\text { a. Penyerangan secara } \\
\text { seksual sering } \\
\text { dilakukan oleh } \\
\text { seorang yang } \\
\text { dipercaya korban } \\
\text { seperti suami, ayah, } \\
\text { anggota keluarga } \\
\text { lainnya. dokter, } \\
\text { pelatih, pembimbing } \\
\text { rohani, temen, } \\
\text { pemimpin } \\
\text { perusahaan atau } \\
\text { teman kencan. } \\
\text { Umumnya pelaku } \\
\text { menjebak atau } \\
\text { mengancam korban. } \\
\text { Dua pertiga dari } \\
\text { penyerangan seksual } \\
\text { terjadi didalam } \\
\text { rumah tangga } \\
\text { (Morris, 2002). } \\
\text { b. Ketakutan adanya } \\
\text { kekerasan membatasi } \\
\text { kehidupan } \\
\text { perempaun } 42 \%, \\
\text { perempaun merasa } \\
\text { tidak aman berjalan } \\
\text { disekitar lingkungan } \\
\text { rumahnya pada } \\
\text { malam hari hanya } 10 \\
\text { \% laki-laki saja yang } \\
\text { merasa begitu. Di } \\
\text { Kanada pada musim } \\
\text { dingin pukul } 3.30 \\
\text { sore keadaan sudah } \\
\text { mulai gelab, malahan } \\
\text { dibagian utara lebih } \\
\text { cepat lagi, lebih dari } \\
\text { sepertiga (37 \%) } \\
\text { perempaun kawatir }\end{array}$ & $\begin{array}{l}\text { b. Sebuah pemantauan yang } \\
\text { dilakukan oleh Kalyanamitra } \\
\text { selama setahun } 1997 \text { sampai } \\
\text { awal maret } 1999 \text { terdapat } \\
\text { berita yang dimuat didalam } \\
\text { suarat kabar menunjukkan } \\
\text { terjadi peningkatan kasus } \\
\text { korban perkosaan dari } 299 \\
\text { kasus pada tahun } 1997 \\
\text { menjadi } 338 \text { kasus pada tahun } \\
\text { 1998 (Farha, 2000). } \\
\text { d. Dalam sebuah studi mngenai } \\
\text { tindak kekerasan erhadap } \\
\text { perempuan di SUMUT } \\
\text { ditemukan peningkatan kasus } \\
\text { pencabulan dari 15 kasus pada } \\
\text { tahun 1999 menjadi 19 kasus } \\
\text { pada tahun 2000 (Pusat } \\
\text { Informasi dan Komunikasi } \\
\text { Perempaun (PIKP), SUMUT } \\
\text { 2001 dalam Sofian, 2002). }\end{array}$ \\
\hline
\end{tabular}




\begin{tabular}{|c|c|c|}
\hline & $\begin{array}{l}\text { jika sendirian } \\
\text { didalam rumah } \\
\text { mereka didalam } \\
\text { rumah tangga mereka } \\
\text { pada saat sore atau } \\
\text { malam hari (Morris, } \\
\text { 2002). }\end{array}$ & \\
\hline $\begin{array}{l}\text { Kekerasan secara } \\
\text { fisik, seksual dan } \\
\text { psikologis yang } \\
\text { dilakukan atau } \\
\text { dibenarkan oleh } \\
\text { Negara }\end{array}$ & $\begin{array}{l}\text { a. Perempuan yang } \\
\text { mempunyai } \\
\text { keterbatasan bahasa } \\
\text { resmi yang } \\
\text { digunakan sehar-hari } \\
\text { menemui banyak } \\
\text { kesulitan terhadap } \\
\text { akses dan pelayanan } \\
\text { dan sistem hukum } \\
\text { yang berlaku. Ketika } \\
\text { kedua hal ini sulit } \\
\text { dijangkau, } \\
\text { perempuan } \\
\text { bertambah sulit untuk } \\
\text { melepas dari } \\
\text { kekerasan (Morris, } \\
\text { 2002). } \\
\text { b. Pemerintah India } \\
\text { secara aktif telah } \\
\text { melakukan kekerasan } \\
\text { terhadap hak } \\
\text { reproduksi } \\
\text { perempuan. } \\
\text { Sterilisasi merupakan } \\
\text { metode kontrasepsi } \\
\text { yang dipaksakan } \\
\text { terhadap perempaun } \\
\text { miskin ketika mereka } \\
\text { telah berumur } 21 \\
\text { tahun ( RH. Afinity } \\
\text { Group Meeting, } \\
\text { 1999). }\end{array}$ & $\begin{array}{l}\text { d. Dalam sebuah studi yang } \\
\text { dilakukan di daerah } \\
\text { Banjarnegara Jawa Tengah } \\
\text { yang melibatkan } 10 \text { desa yang } \\
\text { tersebar di } 3 \text { Kecamatan } \\
\text { ditemukan adanya bentuk } \\
\text { kekerasan yang dilakukan } \\
\text { pemerintah atau penyelenggara } \\
\text { Negara yaitu (Sodikin dalam } \\
\text { fatayat edisi II/April, 2002) } \\
\text { 1) Diberlakukannya UU dan } \\
\text { peraturan yang bias gender } \\
\text { 2)Larangan bagi perempaun } \\
\text { telah menikah untuk memiliki } \\
\text { nomor pajak sendiri. } \\
\text { Minimnya keanggotaan } \\
\text { legislative perempaun di DPR } \\
\text { Minimnya pegawai perempaun } \\
\text { dalam instansi pemerintahan } \\
\text { pada posisi strategis, sehingga } \\
\text { berpengaruh terhadap kebijakan } \\
\text { yang tidak responsif gender. }\end{array}$ \\
\hline
\end{tabular}

Sumber : Kompas 30 September 2002

Data di atas menunjukkan fakta kekerasan yang selama ini terjadi baik di dunia maupun di Indonesia. Sekarang yang menjadi persoalan juga adalah sangat sulit untuk mengukur tepat luasnya kekerasan terhadap perempuan, karena ini berarti harus memasuki wilayah peka kehidupan perempuan yang mana perempuan sendiri enggan membicarakannya. Namun demikian terdapat banyak studi yang melaporkan mengenai jenis kekerasan yang sangat meluas yaitu kekerasan dalam rumah tangga, khususnya kekerasan yang dilakukan oleh suami atau pasangan. 
Misalnya saja data-data UNIFEM yaitu dana PBB Untuk Perempuan, menyebutkan bahwa di Turki, jumlah perempuan yang mengalami kekerasan oleh pasangan mencapai $57.9 \%$ pada tahun 1998. Di India, jumlah tersebut mencapai $49 \%$ pada tahun 1999, di Amerika Serikat mencapai 22,1\%. Dan di Bangladesh, laporan terakhir tahun 2000 menyebutkan 60\% perempuan menikah mengalami kekerasan oleh suami. ${ }^{10}$ (Juliani Wahjana, 2000).

Diperkirakan angka-angka tersebut tidak mencerminkan keadaan yang sesungguhnya mengingat masalah kekerasan yang satu ini masih dianggap tabu karena menyangkut kehidupan intim suami-istri. Banyak istri yang tidak melaporkan atau justru menutupi-nutupi masalah ini karena takut akan cemoohan atau untuk melindungi nama baik keluarga. Ironis bahwa di dalam ranah rumah tangga yang mana perempuan memberikan tenaga untuk mengurus dan merawat anggota yang lain, justru disitulah jutaan perempuan mengalami kekerasan oleh orang-orang terdekat mereka.

Di Indonesia data mengenai kekerasan mengalami peningkatan setiap tahun, itupun tidak semua dapat tercatat, karena ada tindak kekerasan yang sulit untuk diungkap, seperti halnya kasus kekerasan dalam rumah tangga. Matan Menteri Negara Pemberdayaan Perempuan era Gus Dur Khofifah Indar Parawansa mengatakan bahwa tingkat kekerasan yang dialami perempuan Indonesia sangat tinggi. Sekitar 24 juta perempuan atau 11,4 \% dari total penduduk Indonesia pernah mengalami tindak kekerasan. Tindak kekerasan dominan yang dialami oleh perempuan Indonesia adalah kekerasan domestik atau kekerasan dalam rumah tangga misalnya penganiayaan, perkosaan, pelecehan, atau suami berselingkuh. Sedangkan mengenai kekerasan seksual, LSM Perempuan Kalyanamitra dalam hasil penelitiannya menyatakan bahwa setiap lima jam terjadi satu kasus perkosaan. ${ }^{11}$

Sebagaimana hanya komitmen bangsa-bangsa lain di dunia. Indonesia setuju terhadap hasil konverensi sedunia tentang penghapusan kekerasan terhadap perempuan yang diselenggarakan pada tanggal 29 Juli 1980, dengan turut

\footnotetext{
${ }^{10}$ Juliani Wahjana, 2000.

${ }^{11}$ Suara Merdeka, 22 Desember 2000
} 
berpartisipasi dalam usaha-usaha Internasional menghapus segala bentuk diskriminasi terhadap perempuan. Indonsia telah meratifikasi pasal-pasal CEDAW kecuali pada pasal 29 (1) CEDAW yang memuat tentang cara penyelesaian setiap perselisihan antar Negara peserta konvensi khususnya mengenai penafsiran atau penerapan ketentuan konvensi, dengan persyaratan tertentu pemerintah Indonesia menyatakan tidak bersedia mengikat diri pada ketentuan tersebut. $^{12}$

Risalah pasal-pasal tentang CEDAW mengenai penghapusan segala bentuk diskriminasi terhadap wanita (Convention on the Elimination of all form of Discrimination Against Women) terdiri dari 6 bagian dan 30 pasal, yaitu:

Bagian pertama, mengenai pengutukan terhadap segala bentuk diskriminasi terhadap perempuan dan upaya penegakan terhadap perempuan dan upaya menegakkan hak asas persamaan hak dan kewajiban antara pria dalam undang-undang dasar nasional.

Bagian Kedua, mengenai kewajiban Negara-negara peserta membuat peraturan penghapusan diskriminasi terhadap perempuan dalam bidang politik, dan kehidupan kemasyarakatan negaranya.

Bagian ketiga, mengenai kewajiban Negara-negara peserta membuat peraturan penghapusan diskriminasi terhadap perempuan dalam bidang pendidikan, pekerjaan, kesehatan dan kehidupan sosial ekonomi.

Bagian Keempat, mengenai kewajiban Negara-negara peserta memberikan persamaan hak wanita dimuka hukum, menghapus diskriminasi yang berhubungan dengan perkawinan dan hubungan kekeluargaan.

Bagian Kelima, mengenai pembentukan panitia Internasional untuk menilai kemajuan implementasi konvensi (CEDAW), dengan pangkal pertimbangan distribusi geografis yang tepat dan unsur-unsur dari berbagai bentuk peradaban manusia sistem hukum utama, panitia dipilih untuk masa jabatan 4 tahun.

Bagian keenam, konvensi tersebut tidak akan mempengaruhi antara pria dan wanita yang meungkin terdapat dengan perundang-undangan disuatu Negara.

${ }^{12}$ Kompas, Maret 2002 
Disamping itu konvensi ini tidak bersifat kaku setiap Negara berhak untuk mengajukan keberatan-keberatannya. ${ }^{13}$

Walaupun dunia telah menyusun deklarasi mengenai penghapusan kekerasan terhadap perempuan dan Indonesia telah meratifikasi convention on the elimination of all form of discrimination against women atau CEDAW, yaitu deklarasi PBB mengenai penghapusan bentuk diskriminasi mengenai penghapusan bentuk pengahapusan diskriminasi terhadap perempuan yang memuat hak dan kewajiban berdasarkan atas persamaan hak dengan pria Indonesia. Masalah kesulitan ekonomi yang melilit bangsa Indonesia telah membuat bangsa ini lupa akan adanya kedua deklarasi tersebut, buktinya kasus kekerasan dan diskriminasi terhadap perempuan di Indonesia, khususnya yang terjadi diranah domestik meningkat setiap tahunnya ${ }^{14}($

Karena itu harus ada upaya untuk menghapus segala tindak kekerasan, meskipun bukan hal yang mudah untuk dilakukan, namun minimal tindakan yang dapat dilakukan adalah mengoptimalkan peran masyarakat termasuk keluarga dan jaminan perlindungan dari Negara, karena itu dalam perspektif HAM dimanana kelurga adalah kesatuan yang sewajarnya serta merupakan inti dari masyarakat mempunyai hak untuk memperoleh perlindungan dari masyarakat dan Negara Dalam (pasal 16 (3) DUHAM) disebutkan bahwa keluarga adalah kesatuan yang sewajarnya serta bersifat pokok dari masyarakat dan berhak mendapat perlindungan dari masyarakat.

Penegasan serupa juga dicantumkan didalam Deklarasi Kairo yang menyebutkan bahwa. Dalam Deklarasi Kairo perlindungan atas hak perempuan diatur didalam pasal-pasal sebagai berikut:

Pasal 5

(a). Keluarga merupakan pondasi masyarakat dan perkawinan merupakan dasar bagi pembentukannya. Laki-laki dan perempuan mempunyai hak

${ }^{13}$ Ibid.

${ }^{14}$ Aina Rumiyati Azis, 2002 
atas perkawinan, dan tidak ada pembatasan dari ras, warna kulit atau kebangsaan akan mencegah mereka untuk memperoleh hak ini.

(b). Masyarakat dan Negara akan menghapuskan halangan terhadap perkawinan dan harus mempermudah prosedur perkawinan. Mereka harus menjamin perlindungan keluarga.

Pasal 6

(a) Perempuan dan laki-laki adalah setara dalam martabat sebagai manusia, dan mempunyai hak yang dinikmati ataupun kewajiban yang dilaksanakan; ia mempunyai kapasitas sipil dan kemandirian keuangannya sendiri, dan hak untuk mempertahankan nama silsilahnya.

(b) Suami bertanggungjawab atas dukungan dan kesejahteraan keluarga.

Pasal dalam deklarasi kaero tersebut memiliki dua hal penting yaitu selain pengakuan terhadap kesetaran perempuan dan laki-laki, deklarasi tersebut juga memberikan pengakuan terhadap kebebasan membentuk rumah tangga Deklarasi tersebut menunjukkan adopsi terhadap kritik dan pandangan feminis Muslim yang mempromosikan hak dan kebebasana perempuan baik diruang publik maupun privat. $^{15}$

Dalam garis besar yang diterapkan dalam konvensi mengenai penghapsan semua bentuk diskriminasi wanita, perlu sekali realisasi tanpa ditunda-tunda, penghapusan diskriminasi terhadap wanita itu juga harus ada lewat UndangUndang maupaun ketentuan hukum. Disamping itu juga harus ada perubahan paradigma lama yang menganggap rendah wanita.

- Pendidikan keluarga. Ibu mempunyai fungsi sosial dan tanggungjawab bersama dalam mengasuh anak.

- Persamaan pria dan wanita dalam segi kehidupan benegara (pemilu, lembaga pemerintah dan non pemerintah), juga persamaan kesempatan kerja upah jaminan sosial dan lain-lain tetap sama.

- Ibu hamil atau kawinpun memiliki hak untuk efektif kerja.

${ }^{15}$ ELSAM, 1998 
Negara juga harus memperhatikan wanita pedesaan dan perannya dan menghapus diskriminasi yang ada, sehingga partisipasi dalam arti luas menjadi perhatian 16

Bagaimana komitmen Negara dan masyarakat dalam persoalan deskriminasi terhadap wanita termasuk permasalahan KDRT? Meskipun banyak fakta menyebutkan kekerasan ditingkat dan jumlah yang banyak seperti yang diuraikan dalam pembahasan sebelumnya. Di Jakarta pada tanggal 24 November 1999 ada komitmen besar dari masyarakat. Maupun Negara mulai RAN-PKTP (Rencana Aksi Nasional Penghapusan Kekerasan terhadap Perempuan) yaitu rencana aksi yang dilakukan oleh Negara bersama masyarakat dalam upaya mencapai situasi yang tidak mentoliler sekecil apapun segala bentuk tindak kekerasan terhadap perempuan. $^{17}$

Kemudian pada tanggal 24 November 1999 di Jakarta telah dilaksanakan penandatanganan Deklarasi Komitmen Negara dan masyarakat untuk penghapusan kekerasan terhadap perempuan yang diwakili semua unsur Negara dan masyarakat baik lembaga legislatif, eksekutif, yudikatif organisasi non pemerintah, aktifis dan korban kekerasan serta media masa. Deklarasi komitmen terhadap Negara dan masyarakat untuk menghapus kekerasan terhadap perempuan tersebut merupakan langkah lanjut dari diterimanya "Zero Tolerancy Policy " yaitu tidak ditolelernya segala bentuk dan sekecil apapun kekerasan terhadap perempuan, keselamatan dan keamanan perempuan harus merupakan prioritas bagi semua pihak. ${ }^{18}$

Berikut isi deklarasi Negara dan masyarakat dalam upaya mengahapus kekerasan terhadap perempuan yang ditandatangani pada tanggal 24 November 1999 di Jakarta :

\section{DEKLARASI}

Komitmen Negara dan Masyarakat Untuk pengapusan Kekerasan Terhadap Perempuan

\footnotetext{
${ }^{16}$ Masyhur Effendi, tt, 14.

${ }^{17}$ Kompas, Senin, 4 Maret 2002.

${ }^{18}$ Ibid
} 
Memperhatikan adanya berbagai kekerasan yang selama ini terjadi, baik di lingkungan keluarga, tempat kerja, masyarakat dan negara dalam bentuk kekerasan fisik, psikis, seksual dan ekonomi yang dilakukan oleh perorangan, kelompok-kelompok yang ada di masyarakat, maupun oleh instansi negara sehingga menimbulkan penderitaan bagi perempuan baik anak, dewasa maupun usia lanjut.

Melihat bahwa kekerasan yang terjadi diatas akibat dari relasi kekuasaan yang tidak seimbang baik relasi gender, kelas, usia, etnis, ras, maupun kenegaraan dimana kekerasan tersebut sudah mengakar dan menjadi sistem yang begitu kuat.

Banyak pihak berperan dalam "melembagakan" kekerasan dan menjadikan sebagai kebiasaan dalam berrelasi (hubungan) secara pribadi, bermasyarakat dan bernegara. Menyadari bahwa kita adalah bagian dari masyarakat Internasional yang telah membuat komitmen internasional dalam upaya penghapusan kekerasan terhadap perempuan. Menyadari bahwa keadaan tersebut harus dihentikan dan diperbaiki dengan sungguh-sungguh demi terciptanya rasa aman, damai, adil dan sejahtera dengan memegang prinsip-prinsip keadilan gender, peduli lingkungan. demokratis dan menjunjung tinggi hak asasi manusia termasuk didalamnya perempuan. Dengan ini kami negara dan masyarakat Indonesia. Menyatakan komitmen bersama untuk menghapuskan kekerasan terhadap perempuan dengan:

Pertama Meningkatkan tanggung jawab semua pihak untuk menghentikan dan tidak mentolerir segala bentuk kekerasan terhadap perempuan.

Kedua Meningkatkan perlindungan hak asasi manusia dan menciptakan rasa aman kepada semua warga negara khususnya perempuan.

Ketiga Membangun gerakan bersama untuk mencegah dan menghapuskan kekerasan terhadap perempuan disegala lini kehidupan.

Keempat Mengupayakan penyelesaian kasus-kasus kekerasan yang terjadi secara adil dan tuntas, termasuk menindak tegas pelaku kekerasan serta memberikan perlindungan kepada korban dan saksi.

Jakarta, 24 Nopember 1999

Langkah tersebut merupakan salah satu komitmen positif terhadap perhatian masyarakat dan negara terhadap kekerasan yang selama ini sering dialami oleh perempuan. Baik ditinjau dari segi apapun segala bentuk kekerasan merupakan perbuatan terhadap pelanggaran hak-hak asasi manusia, karena itu dengan prinsipprinsip negara berdasarkan atas hukum, upaya yang dilakukan dalam mencegah 
terjadi dan penghapusan segala bentuk kekerasan terhadap perempuan perlu ditingkatkan dan diwujudkan secara nyata.

Komitmen tersebut tidak hanya diwujudkan dengan menerbitkan UndangUndang yang memberikan jaminan perlindungan terhadap perempuan, namun juga harus didukung sistem hukum maupun moralitas pejabat negara yang mumpuni dan bertanggungjawab terhadap orang-orang yang dirampas kemerdekaannya serta sistem pengadilan profesional.

\section{Pandangan HAM Terhadap Kekerasan Suami Terhadap Istri}

Rumah tangga pada dasarnya dibangun atas dasar ibadah, perasaan cinta kasih, penuh ketenangan dan kebahagiaan. Masing-masing anggota keluarga harus mendapatkan jaminan ketenangan dan keamanan tanpa adanya unsur kekerasan. Apabila terdapat kekerasan dalam rumah tangga dalam bentuk apapun yang akan mengakibatkan hak-hak dasar suami atau istri teraniaya baik secara fisik (seperti pemukulan, menggigit, atau pencederaan terhadap fisik) maupun non fisik yang akan berakibat pada perendahan citra dan kepercayaan diri (melalui kata-kata atau perbuatan yang tidak disukai) dapat dikategorikan sebagai salah satu bentuk pelanggaran terhadap hak asasi manusia. Begitu juga dengan perlakuan dan tindakan dalam bentuk kekerasan psikologis yang akan mengakibatkan terabaikannya hak asasi manusia unttuk memperoleh perlakuan baik dalam segala hal Oleh karena itu, dalam konteks rumah tangga istri maupun suami harus memahami dan saling menghormati hak-hak masing-masing sebagai individu yang merdeka dalam bentuk yang telah disepakati oleh kedua belah pihak secara adil dan setara.

Kehidupan rumah tangga dianggap sebagai salah satu elemen penting dalam masyarakat yang juga diatur oleh agama melalui Fiqh keluarga untuk mendapatkan legitimasi hukum yang memunculkan apa yang disebut dengan hak dan kewajiban bagi suami maupun istri. 


\section{KESIMPULAN}

Kekerasan dalam rumah tangga yang masih menjadi polemik sampai sekarang merupakan salah satu permasalahan yang harus dikaji dari berbagai aspek baik hukum, budaya maupun penafsiran agama untuk mendapatkan alternatif penyelesaiannya karena dapat merugikan salah satu pihak baik suami maupun istri. Apabila terjadi perlakuan dari suami maupun istri yang menyebabkan terabaikannya hak-hak masing-masing pihak, maka keutuhan keluarga dapat terancam dan tujuan awal dilaksanakannya pernikahan tidak akan tercapai yaitu membangun keluarga yang sakinah mawaddah wa rahmah. Suatu kondisi keluarga yang menjamin kebahagiaan dan keamanan seluruh anggota keluarga.

Berbagai kekerasan yang lahir dari pemahaman yang bias gender terhadap peran dan posisi perempuan yang berbeda dalam rumah tangga tidak dibenarkan menurut perspektif deklarasi Undang-Undang Hak Asasi Manusia yang sudah disepakati secara internasional karena segala tindakan yang mengarah pada terabaikannya hak-hak dasar yang dimiliki masing-masing individu. Jadi tidak dibenarkan apabila terjadi kekerasan dalam bentuk apapun yang berakibat penganiayaan secara fisik maupun non fisik 


\section{BIBLIOGRAFI}

Nawawi, Muhamad Ibnu Umar Al-Bantany. Syarh Uqud Al-Lujain Huquq Al-Zayjain, Surabaya: Al-Hidayah, tth.

Azis, Aina Rumiyati. 2002.

Bali Post, Juli, 2002.

Muhammad Irfan, Abdul Wahid. Perlindungan terhadap Korban Kekerasan Seksual 2001, 65.

Nadia, Ita F. Hak Perempuan sebagai HAM. Ttp: deminasi HAM, 2000, 119.

Suara Merdeka, 22 Desember 2000.

Kompas, Maret 2002.

ELSAM, 1998.

Masyur Effendi, tt, 14.

Kompas, Senin, 4 Maret 2002.

Wahjana, Juliani. 2000. 